\title{
PENGARUH KUALITAS LAYANAN TERHADAP KEPUASAN PELANGGAN PRODUK LISTRIK PRABAYAR DI PT.PLN (PERSERO) GRESIK
}

\author{
Fitroh Tri Kurnia Maulidina \\ Program Studi Manajemen Fakultas Ekonomi dan Bisnis \\ Universitas Muhammadiyah Gresik, Jawa Timur, Indonesia, dinachankby@ gmail.com \\ Budiyono Pristyadi \\ Program Studi Manajemen Fakultas Ekonomi dan Bisnis \\ Universitas Muhammadiyah Gresik, Jawa Timur, Indonesia, budipristyadi@ gmail.com
}

\begin{abstract}
This study aims to analyze the influence of service quality (direct evidence, reliability, responsiveness, assurance and concern) on the satisfaction of prepaid electricity customers at PT PLN (Persero) Gresik, case study: Ngipik Village, Gresik District. This study uses a quantitative approach. the subject of this study was prepaid electricity customers of PT. PLN (Persero) Gresik, with 120 samples. Data analysis techniques used are multiple linear regression analysis. The regression results obtained t count of 3.571 while the table amounted to 1.980 which means direct evidence has an effect on customer satisfaction at PT. PLN (Persero) Gresik. Reliability variable has $t$ count of 2.856 while t table is 1.980 , therefore the reliability variable influences customer satisfaction at PT. PLN (Persero) Gresik. The responsiveness variable has a t count of 2.696 while the t table is 1.980 so the responsiveness variable influences customer satisfaction at PT. PLN (Persero) Gresik. The guarantee variable has a t count of 3.039 while the t table is 1.980 so the guarantee variable influences customer satisfaction at PT. PLN (Persero) Gresik. Concern variables have t arithmetic of 3.410 while $t$ table is 1.980 so that the variables of concern affect customer satisfaction at PT. PLN (Persero) Gresik. direct evidence variables, reliability, responsiveness, assurance and concern have a simultaneous and significant effect on customer satisfaction.
\end{abstract}

Keywords : Direct, evidence, reliability, responsive, assurance, care

\begin{abstract}
ABSTRAK
Penelitian ini bertujuan untuk menganalisis pengaruh kualitas layanan (bukti langsung, keandalan, daya tanggap, jaminan dan kepedulian) terhadap kepuasan pelanggan listrik prabayar di PT PLN (Persero) Gresik, studi kasus: Desa Ngipik, Kabupaten Gresik. Penelitian ini menggunakan pendekatan kuantitatif. Subjek penelitian ini adalah pelanggan listrik prabayar PT. PLN (Persero) Gresik, dengan 120 sampel. Teknik analisis data yang digunakan adalah analisis regresi linier berganda. Hasil regresi diperoleh t hitung sebesar 3,571 sedangkan t tabel sebesar 1,980 yang berarti bukti langsung berpengaruh terhadap kepuasan pelanggan di PT. PLN (Persero) Gresik. Variabel reliabilitas memiliki t hitung 2,856 sedangkan t tabel 1,980, oleh karena itu variabel reliabilitas mempengaruhi kepuasan pelanggan pada PT. PLN (Persero) Gresik. Variabel daya tanggap memiliki t hitung 2,696 sedangkan $t$ tabel adalah 1,980 sehingga variabel daya tanggap mempengaruhi kepuasan pelanggan di PT. PLN (Persero) Gresik. Variabel jaminan memiliki t hitung 3.039 sedangkan t tabel adalah 1.980 sehingga variabel jaminan mempengaruhi kepuasan pelanggan di PT. PLN (Persero) Gresik. Variabel kekhawatiran memiliki t hitung 3,410 sedangkan $\mathrm{t}$ tabel adalah 1,980 sehingga variabel yang menjadi perhatian mempengaruhi kepuasan pelanggan di PT. PLN (Persero) Gresik. Variabel bukti langsung, keandalan, daya tanggap, jaminan dan kepedulian memiliki pengaruh simultan dan signifikan terhadap kepuasan pelanggan.
\end{abstract}

Kata Kunci: Bukti, Langsung, Keandalan, Tanggap, Jaminan, Perawatan 


\section{PENDAHULUAN}

Perusahaan Listrik Negara atau nama resminya adalah PT.PLN (Persero) merupakan perusahaan BUMN yang mengurusi semua aspek kelistrikan yang ada di Indonesia. Listrik merupakan kebutuhan pokok bagi kehidupan manusia. Ketergantungan manusia akan listrik terjadi karena energi tersebut sangat fleksibel, sehingga dapat dengan mudah diubah menjadi energi dalam bentuk lain untuk menggerakkan peralatan industri, rumah tangga dan lain sebagainya. Konsumsi listrik di Indonesia secara rata-rata adalah 473 $\mathrm{kWh} / \mathrm{kapita}$ pada tahun 2003. Angka ini masih tergolong rendah dibandingkan rata-rata konsumsi listrik dunia yang mencapai $2215 \mathrm{kWh} / \mathrm{kapita}$ (2005) dalam daftar yang dikeluarkan oleh The World Fact Book, Indonesia menempati urutan 154 dari 216 negara yang ada dalam daftar. Rata- rata nasional 352.59. Jumlah pelanggan listrik pada tahun 2015 di Indonesia adalah 57.493.234. PT PLN (Persero) menyatakan jumlah pelanggan prabayar yang menggunakan listrik prabayar sebanyak 13,1 juta pelanggan.

PT.PLN (Persero) menyadari kebutuhan listrik masyarakat yang semakin ketergantungan akan adanya tenaga listrik dengan terus melakukan berbagai kajian untuk meningkatkan mutu pelayanan. Produktivitas PT.PLN (persero) merupakan kemampuan perusahaan jasa dalam menggunakan input untuk menyediakan jasa dengan memenuhi ekspektasi pelanggan. PT.PLN (persero), memiliki dua produk yaitu, Listrik Pascabayar (manual) dan Listrik Prabayar (Listrik Pintar). Listrik Pascabayar (manual) merupakan produk lama dari PLN.

Cara mekanisme penggunaan listrik pascabayar adalah pelanggan menggunakan energi listrik dulu setelah itu membayarnya belakangan. Terkadang hal tersebut secara tidak langsung dapat menimbulkan pembengkakan tagihan listrik pelanggan. Setiap bulan petugas PLN akan mencatat meter, menghitung dan menerbitkan rekening yang harus dibayar pelanggan. petugas PLN akan melakukan penagihan kepada pelanggan yang terlambat atau tidak membayar dan akan memutus aliran listrik jika pelanggan terlambat atau tidak membayar rekening listrik pada jangka waktu yang telah ditentukan. Jika pelanggan tidak melakukan pembayaran sampai jangka waktu yang telah ditentukan, maka akan dikenakan denda. Listrik Prabayar merupakan produk unggulan bagi PT.PLN. Listrik Prabayar merupakan produk inovasi dari PT.PLN (persero), yang tentunya memiliki keunggulan tersendiri dibandingkan dengan listrik pascabayar. Layanan listrik prabayar merupakan bentuk pelayanan PLN dalam menjual energi listrik dengan cara pelanggan membayar dimuka. Pelanggan terlebih dahulu membeli sejumlah nominal energi listrik sesuai dengan yang dibutuhkan. Saat ini Indonesia tercatat sebagai pengguna listrik prabayar terbesar di dunia.

Dari tahun ke tahun, jumlah pelanggan listrik prabayar PLN terus meningkat. Pada tahun lalu, PLN telah menambah 5,3 juta pelanggan baru untuk listrik prabayar. Dengan total pelanggan 13,1 juta, itu berarti 24,3\% dari total pelanggan PLN sebanyak 5,39 juta sudah memakai listrik prabayar. Pemanfaatan listrik prabayar menguntungkan pelanggan karena dengan layanan tersebut pelanggan dapat mengatur pemakaian listrik dan dapat mematok anggaran biaya listrik bulanan. Selain itu, pelanggan juga terlepas 
dari masalah kesalahan catat penggunaan listrik serta terbebas dari sanksi pemutusan telat bayar listrik. Secara otomatis layanan ini juga mengatasi keluhan pelanggan tentang pembacaan meter oleh petugas PLN yang tidak akurat. Pelanggan juga tidak perlu khawatir mati listrik mendadak saat stroom yang tertera di meter sudah habis. Karena secara otomatis, meteran prabayar akan memberikan alarm jika jumlah kilowatt hour sudah mulai habis. Dengan sistem prabayar ini, hal-hal yang tidak diinginkan tidak akan terjadi lagi, sehingga antara pelanggan dan PLN mempunyai hubungan yang baik. Selain itu pula masyarakat pengguna listrik prabayar bisa lebih berhemat dalam pemakaian listik setiap harinya, karena listrik prabayar ini secara tidak langsung dapat mengajak masyarakat berhemat dalam penggunaan listrik, karena pengontrolan pemakaian listrik sepenuhnya ada ditangan pelanggan.

Fenomena yang terjadi saat ini adalah pemerintah sudah mewajibkan semua masyarakat Indonesia beralih menggunakan listrik prabayar. Listrik prabayar lebih efisien dari pada listrik pascabayar. Pelayanan yang diberikan pun berbeda antara listrik prabayar dengan listrik pascabayar. Kecamatan Gresik sendiri, hampir seluruh desa sudah menggunakan listrik prabayar. Hal ini dapat dibuktikan dengan data:

\section{Tabel 1}

Jumlah Pelanggan Listrik Prabayar PT.PLN (Persero) Kecamatan Gresik Tahun 2018

\begin{tabular}{|c|l|c|}
\hline No. & \multicolumn{1}{|c|}{ Kecamatan Gresik } & Listrik Prabayar (Pelanggan) \\
\hline 1. & Kelurahan Sidokumpul & 1076 \\
\hline 2. & Kelurahan Tlogopatut & 225 \\
\hline 3. & Desa Sidorukun & 410 \\
\hline 4. & Desa Pulopancikan & 475 \\
\hline 5. & Desa Tlogobendung & 186 \\
\hline 6. & Kelurahan Bedilan & 260 \\
\hline 7. & Kelurahan Pekauman & 158 \\
\hline 8. & Kelurahan Trate & 315 \\
\hline 9. & Kelurahan Kebungson & 195 \\
\hline 10. & Kelurahan Kemuteran & 135 \\
\hline 11. & Kelurahan Pekelingan & 145 \\
\hline 12. & Kelurahan Karangpoh & 238 \\
\hline 13. & Kelurahan Kroman & 325 \\
\hline 14. & Kelurahan Sukodono & 90 \\
\hline 15. & Kelurahan Desa Lumpur & 525 \\
\hline 16. & Kelurahan Karangturi & 405 \\
\hline 17. & Kelurahan Tlogopojok & 538 \\
\hline 18. & Desa Gapurosukolilo & 283 \\
\hline 19. & Desa Kramatinggil & 189 \\
\hline 20. & Kelurahan Ngipik & 210 \\
\hline 21. & Kelurahan Sukorame & 468 \\
\hline & TOTAL & $\mathbf{6 5 1}$ \\
\hline
\end{tabular}

Sumber: Data dari PT.PLN (Persero) Gresik

Berdasarkan tabel diatas dijelaskan bahwa pelanggan listrik prabayar di Kecamatan Gresik pada tahun 2018 sejumlah 6.851 pelanggan listrik prabayar. Dalam penelitian ini, lebih difokuskan pada pengguna listrik prabayar di desa Ngipik, Kecamatan Gresik. Jumlah masyarakat pengguna listrik prabayar di Desa Ngipik 
sejumlah 210 pelanggan listrik prabayar. Dimana seluruh rumah sudah menggunakan listrik prabayar. Sistem $\mathrm{kWh}$ meter prabayar berbeda bila dibandingkan $\mathrm{kWh}$ meter yang biasa dipakai selama ini (pascabayar), terbuat dari meter elektronik dipasang pelanggan digunakan mengukur pemakaian listrik pelanggan dan memantau serta mengontrolnya. Meteran ini mempunyai beberapa fungsi atau fitur antara lain, mempunyai nomer seri unik, konektor untuk menghubung atau memutus koneksi listrik.

Meter prabayar menyediakan informasi jumlah energi listrik kWh yang masih bisa dikonsumsi. Persediaan kWh bisa ditambah berapa saja dan kapan saja sesuai kebutuhan dan keinginan. Dengan demikian pelanggan mengoptimalkan konsumsi listrik dengan mengatur sendiri jadwal dan jumlah pembelian listrik. Dari fenomena tersebut diketahui bahwa penggunaan listrik prabayar lebih efisien daripada listrik pascabayar. Melalui tabel perbandingan pemakaian listrik prabayar dan pascabayar berikut dilihat efisiensi dari penggunaan listrik prabayar.

Tabel 2

Perbandingan Listrik Prabayar dan Listrik Pascabayar

\begin{tabular}{|l|l|l|}
\hline No & \multicolumn{1}{|c|}{ Listrik Prabayar } & \multicolumn{1}{c|}{ Listrik Pascabayar } \\
\hline 1. & Tidak ada pencatatan kWh meter & Adanya pencatatan $\mathrm{kWh}$ meter \\
\hline 2. & Tidak ada sanksi pemutusan & Adanya sanksi pemutusan \\
\hline 3. & Tidak dikenakan beban bulanan & Dikenakan biaya beban bulanan \\
\hline 4. & Lebih privasi & Privasi tidak terjamin \\
\hline 5. & Dapat mengatur pemakaian listrik sendiri & Tidak dapat mengatur pemakaian listrik \\
\hline \multicolumn{2}{l}{ Sumber: Data dari PT.PLN (Persero) Gresik }
\end{tabular}

Sebagaimana telah diuraikan sebelumnya bahwa kualitas pelayanan menjadi semakin penting bagi organisasi-organisasi penghasil layanan. Menurut Wijaya (2018;31) kualitas layanan yang baik memiliki strategi layanan yang ditentukan dengan jelas dan dikomunikasikan dengan jelas juga memiliki sistem pelayanan customer friendly, yakni bersahabat dengan pelanggan. pemerintah memiliki peran yang sangat besar dalam pembuatan program pelayanan dan kebijakan publik. Dengan demikian tingkat kehidupan masyarakat diharapkan bisa bertambah baik dan maju atas kebijakan pemerintah yang ditetapkan tersebut.Dengan kualitas pelayanan yang baik, maka akan muncul kepuasan dari masyarakat sendiri. Tjiptono (2012: 301)menjelaskan bahwa kepuasan pelanggan merupakan situasi yang ditunjukkan pelanggan ketika mereka menyadari bahwa kebutuhan dan keinginannya sesuai dengan yang diharapkan serta terpenuhi secara baik.

Berdasarkan dengan latar belakang masalah, maka rumusan masalah dalam penelitian ini adalah apakah bukti langsung, keandalan, daya tanggap, jaminan dan kepedulian berpengaruh secara parsial terhadap kepuasan pelanggan produk listrik prabayar PT.PLN (Persero) Gresik.

Tujuan dalam penelitian ini adalah untuk mengetahui bukti langsung, keandalan, daya tanggap, jaminan dan kepedulian berpengaruh parsial terhadap kepuasan pelanggan produk listrik prabayar di PT.PLN (Persero) Gresik. 


\section{TINJAUN PUSTAKA}

\section{Pemasaran Jasa}

Menurut Kotler \& Armstrong (2008;5) pemasaran merupakan sebuah proses perusahaan menciptakan nilai untuk konsumennya dan membangun hubungan kuat dengan konsumen bertujuan untuk menciptakan nilai keuntungan dari konsumen. Pemasaran jasa merupakan tindakan atau kegiatan yang ditawarkan pihak produsen kepada konsumen berupa jasa yang tidak dapat dilihat, diraba, dan didengar namun dapat dirasakan manfaatnya oleh konsumen.

\section{Kualitas Layanan}

Menurut Wijaya (2018;31) kualitas layanan yang baik memiliki strategi ditentukan dengan jelas dan disampaikan dengan jelas pula memiliki sistem pelayanan customer yang friendly, yakni bersahabat dengan pelanggan. Menurt Lewis \& Booms (dalam Tjiptono, 2012) mengartikan kualitas pelayanan secara sederhana, yaitu ukuran seberapa bagus tingkat layanan yang diberikan mampu sesuai dengan ekspektasi pelanggan. Menurut Tjiptono dan Diana (2003) dalam Wijaya (2018;65) terdapat beberapa dimensi kualitas jasa disebut dengan dimensi SERVQUAL yaitu :

1. Keandalan / Reliability

2. Ketanggapan / Responsiveness

3. Jaminan kepastian / Assurance

4. Perhatian / Emphaty

5. Berwujud / Tangible

\section{Bukti Langsung}

Menurut Tjiptono (2008), dimensi tangibles atau bukti fisik berkaitan dengan hal-hal fisik yang menjadi daya tarik pelanggan dengan perusahaan seperti fasilitas fisik, perlengkapan, penampilan karyawan, serta material yang digunakan perusahaan. Konsumen dapat menilai suatu kualitas layanan dengan bukti langsung yang dirasakan oleh konsumen. Berikut indikator dari bukti langsung atau tangibles ;

1. Karyawan berpenampilan rapi

2. Kondisi sarana dan SDM

3. Memiliki ruangan kantor yang nyaman dan terjaga kebersihannya

\section{Keandalan}

Menurut Wijaya $(2018 ; 65)$ dimensi reability atau keandalan ini berkaitan dengan bagaimana kemampuan sebuah perusahaan memberikan kinerja layanan secara akurat sejak awal dan menyampaikan jasanya sesuai dengan waktu yang sudah disepakati, tanpa membuat kesalahan. Berikut indikator dari reliability atau keandalan:

1. Menyediakan jasa secara benar

2. Kecekatan dalam melayani pelanggan

3. Ketelitian pengerjaan pelayanan 


\section{Daya Tanggap}

Menurut Wijaya (2018:31) keinginan para staf untuk mebantu para pelanggan dan memberikan pelayanan dengan tanggap dan peduli terhadap keluhan atau harapan pelanggan. Dimensi responsive atau daya tanggap ini berkaitan dengan bagaimana kemampuan dan kesediaan setiap karyawan memberikan bantuan terhadap pelanggan, memberikan informasi yang jelas kapan jasa diberikan, merespon apa yang diinginkan, dan memberikan jasa secara cepat. Berikut indikator daya tamggap atau responsive:

1. Kesediaan staf membantu pelanggan

2. Pelayanan cepat dan tanggap

3. Mengangkat/ menerima telepon dengan segara saat dihubungi

\section{Jaminan}

Menurut Tjiptono (2010:301) dimensi assurance atau jaminan ini memiliki fungsi dalam menumbuhkan kepercayaan konsumen terhadap perusahaan dan perusahaan bisa memberikan rasa aman dalam proses pemakaian jasa. Jaminan juga berarti bahwa setiap karyawan selalu memberikan sikap dan etika yang baik serta menguasai pengetahuan akan produk guna menangani setiap hal yang ditanyakan konsumen seputar masalah layanan. Berikut indikator assurance:

1. Konsisten bersikap sopan, ramah dan tenang saat melayani pelanggan

2. Kemampuan staf untuk menjawab setiap pertanyaan pelanggan

3. Pelanggan merasa aman dalam melakukan transaksi

\section{Kepedulian}

Menurut Wijaya (2018:31), sifat dan kemampuan untuk memberikan perhatian penuh kepada pelanggan, komunikasi yang baik dan memahami kebutuhan pelanggan secara individual. Dimensi emphaty atau kepedulian ini memiliki arti bahwa setiap perusahaan memahami permasalaan dan bertindak sesuai dengan kepentingan pelanggannya, memiliki waktu operasional yang memberikan kenyamanan, serta memberi perhatian secara personal pada pelanggan. Berikut indikator dari emphaty atau kepedulian:

1. Memberikan perhatian secara individual kepada para pelanggan

2. Memahami keinginan sesuai kebutuhan yang diharapkan pelanggan

3. Mengutamakan kepentingan pelanggan dengan sungguh-sungguh

\section{Kepuasan Pelanggan}

Menurut Tjiptono (2012:301) menjelaskan bahwa kepuasan pelanggan merupakan situasi yang ditunjukkan oleh pelanggan ketika mereka menyadari bahwa kebutuhan dan keinginannya sesuai dengan yang diharapkan serta terpenuhi secara baik. menurut Kotler \& Keller (2009). Indikator kepuasan pelanggan:

1. Kualitas pelayanan sesuai harapan

2. Kinerja produk listrik prabayar

3. Kualitas produk listrik prabayar 


\section{Kerangka Konseptual}

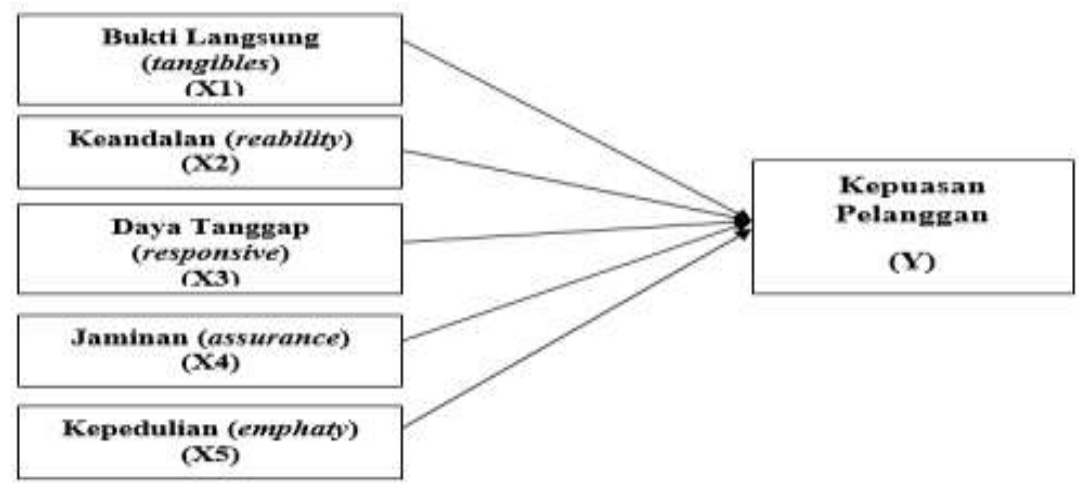

Keterangaа.

$\stackrel{\text { Secara Parsial }}{\longrightarrow}$

Gambar 1

Kerangka Konseptual

\section{METODOLOGI PENELITIAN}

\section{Pendekatan Penelitian}

Pendekatan penelitian ini merupakan penelitian Kuantitatif.

\section{Lokasi Penelitian}

Lokasi penelitian bagian departemen pemasaran dan pelayanan pelanggan bertempat di PT.PLN (Persero) Gresik. Fokus penelitian di Desa Ngipik, jalan Dr.Sutomo dan Jalan Jendral Achmad Yani, Kec.Gresik, Kabupaten Gresik.

\section{Populasi dan Sampel}

Jumlah populasi dalam penelitian ini adalah 210 pelanggan listrik prabayar di Desa Ngipik, kecamatan Gresik. Pengambilan sampel menggunakan teori Sugiyono (2015) menyatakan bahwa ukuran sampel yang tepat adalah 30-500 responden dan jumlah sampel yang harus diambil dalam suatu penelitian adalah 15-20 kali jumlah variabel yang digunakan. Maka dari itu, banyaknya variabel yang digunakan dalam penelitian ini adalah 6 x $20=120$. Sehingga jumlah sampel penelitian ini sejumlah 120 responden.

\section{Jenis dan Sumber Data}

\section{Jenis Data}

Jenis data dalam penelitian ini adalah data primer, yaitu data yang dikumpulkan langsung oleh peneliti dari jawaban responden dengan menggunakan kuesioner. Sumber data dalam penelitian ini dari hasil jawaban responden.

\section{Teknik Pengambilan Data}

Teknik pengambilan data dalam penelitian ini adalah dengan menggunakan metode angket (kuesioner). 


\section{Pengukuran Variabel}

Pengukuran penelitian ini adalah dengan menggunakan skala likert.

1. Kategori Sangat Setuju (SS) diberi skor $=5$

2. Kategori Setuju (S) diberi skor $=4$

3. Kategori Kurang Setuju (KS) diberi skor $=3$

4. Kategori Tidak Setuju (TS) diberi skor $=2$

5. Kategori Sangat Tidak Setuju (STS) diberi skor $=1$

\section{Teknik Analisis Data}

Metode yang digunakan adalah Regresi linear berganda. Analisis ini digunakan untuk mengetahui hubungan variabel bebas $(\mathrm{X})$ terhadap variabel terikat $(\mathrm{Y})$. Rumus yang digunakan regresi linier berganda sebagai berikut:

$$
\mathrm{Y}=\mathrm{a}+\mathrm{b}_{1} \mathrm{X}_{1}+\mathrm{b}_{2} \mathrm{X}_{2}+\mathrm{b}_{3} \mathrm{X}_{3}+\mathrm{b}_{4} \mathrm{X}_{4}+\mathrm{b}_{5} \mathrm{X}_{5}+\mathrm{e}
$$

\section{HASIL PENELITIAN}

\section{Uji Instrumen Penelitian}

\section{Uji Validitas}

Hasil uji validitas penelitian ini dengan $r$ tabel sebesar 0,179. Maka $r$ hitung $>r$ tabel, seluruh butir peryataan dari seluruh variabel independen dan dependen terbukti valid.

Tabel 3

Rekapitulasi Hasil Uji Validitas

\begin{tabular}{|c|c|c|c|c|c|}
\hline No. & Butir Pernyataan & r Hitung & r Tabel & Sig & Keterangan \\
\hline $\mathbf{1 .}$ & $\mathbf{X 1}$ & & & & \\
\hline & $\mathrm{X} 1.1$ & 0,881 & 0,179 & 0,000 & Valid \\
\hline & $\mathrm{X} 1.2$ & 0,865 & 0,179 & 0,000 & Valid \\
\hline & $\mathrm{X} 1.3$ & 0,874 & 0,179 & 0,000 & Valid \\
\hline $\mathbf{2 .}$ & $\mathbf{X 2}$ & & & & \\
\hline & $\mathrm{X} 2.1$ & 0,691 & 0,179 & 0,000 & Valid \\
\hline & $\mathrm{X} 2.2$ & 0,764 & 0,179 & 0,000 & Valid \\
\hline & $\mathrm{X} 2.3$ & 0,709 & 0,179 & 0,000 & Valid \\
\hline $\mathbf{3 .}$ & $\mathbf{X 3}$ & & & & \\
\hline & $\mathrm{X} 3.1$ & 0,751 & 0,179 & 0,000 & Valid \\
\hline & $\mathrm{X} 3.2$ & 0,775 & 0,179 & 0,000 & Valid \\
\hline & $\mathrm{X} 3.3$ & 0,735 & 0,179 & 0,000 & Valid \\
\hline $\mathbf{4 .}$ & $\mathbf{X 4}$ & & & & \\
\hline & $\mathrm{X} 4.1$ & 0,858 & 0,179 & 0,000 & Valid \\
\hline & $\mathrm{X} 4.2$ & 0,860 & 0,179 & 0,000 & Valid \\
\hline & $\mathrm{X} 4.3$ & 0,841 & 0,179 & 0,000 & Valid \\
\hline $\mathbf{5 .}$ & $\mathbf{X 5}$ & & & & \\
\hline & $\mathrm{X} 5.1$ & 0,801 & 0,179 & 0,000 & Valid \\
\hline & $\mathrm{X} 5.2$ & 0,844 & 0,179 & 0,000 & Valid \\
\hline & $\mathrm{X} 5.3$ & 0,784 & 0,179 & 0,000 & Valid \\
\hline $\mathbf{6 .}$ & $\mathbf{Y}$ & & & & \\
\hline & $\mathrm{Y} 1$ & 0,867 & 0,179 & 0,000 & Valid \\
\hline & $\mathrm{Y} 2$ & 0,893 & 0,179 & 0,000 & Valid \\
\hline & $\mathrm{Y} 3$ & 0,887 & 0,179 & 0,000 & Valid \\
\hline
\end{tabular}




\section{Uji Reliabilitas}

Pengukuran reliabel dengan menggunakan aplikasi SPSS 17, uji statistik yang digunakan Cronbach Alfa $(\alpha)$ dikatakan reliabel jika nilai $\alpha>0,70$. Dari hasil penghitungan hasil nilai cronbach alpha lebih besar dari 0,7 dan dinyatakan reliabel.

Tabel 4

Hasil Uji Reliabilitas

\begin{tabular}{|c|c|c|c|c|}
\hline No. & Item & Cronbach Alpha & Alpha & Keterangan \\
\hline $\mathbf{1 .}$ & Bukti langsung & 0,844 & 0,70 & Reliabel \\
\hline $\mathbf{2 .}$ & Keandalan & 0,817 & 0,70 & Reliabel \\
\hline 3. & Daya tanggap & 0,730 & 0,70 & Reliabel \\
\hline $\mathbf{4 .}$ & Jaminan & 0,812 & 0,70 & Reliabel \\
\hline $\mathbf{5 .}$ & Kepedulian & 0,737 & 0,70 & Reliabel \\
\hline 6. & Kepuasan pelanggan & 0,858 & 0,70 & Reliabel \\
\hline
\end{tabular}

\section{Uji Asumsi Klasik}

\section{Uji Multikolinearitas}

Dari hasil pengolahan data dibawah ini diperoleh nilai tolerance value lebih besar dari 0,10 atau sama dengan nilai VIF lebih kecil dari 10 maka dapat disimpulkan bahwa model regresi menunjukkan tidak terjadi multikolinearitas.

Tabel 5

Hasil Uji Multikolinearitas

\begin{tabular}{|c|c|c|c|}
\hline Variabel & Tolerance & VIF & Keterangan \\
\hline Bukti langsung & 0.935 & 1.069 & Nonmultikolinearitas \\
\hline Keandalan & 0.723 & 1.384 & Nonmultikolinearitas \\
\hline Daya tanggap & 0.698 & 1.432 & Nonmultikolinearitas \\
\hline Jaminan & 0.838 & 1.193 & Nonmultikolinearitas \\
\hline Kepedulian & 0.842 & 1.188 & Nonmultikolinearitas \\
\hline
\end{tabular}

\section{Uji Heteroskedastisitas}

Berdasarkan output dibawah ini menunjukkan bahwa nilai uji glejser dapat diketahui hasil sig > 0,05. Untuk nilai sig bukti langsung sebesar 0,463 , nilai sig keandalan 0,775 , nilai sig daya tanggap 0,118 , nilai sig jaminan 0,234 dan nilai sig pada variabel kepedulian 0,691. Maka dapat disimpulkan bahwa tidak terdapat gejala heterokedastisitas.

Tabel 6

Hasil Uji Heteroskedastisitas

\begin{tabular}{|c|l|l|}
\hline Vaiabel & Sig & Keterangan \\
\hline Bukti langsung & 0.463 & Tidak terdapat gejala heterokedastisitas \\
\hline Keandalan & 0.775 & Tidak terdapat gejala heterokedastisitas \\
\hline Daya tanggap & 0.118 & Tidak terdapat gejala heterokedastisitas \\
\hline Jaminan & 0.234 & Tidak terdapat gejala heterokedastisitas \\
\hline Kepedulian & 0.691 & Tidak terdapat gejala heterokedastisitas \\
\hline
\end{tabular}




\section{Uji Normalitas}

Berdasarkan hasil output dibawah, dapat diketahui bahwa nilai signifikansi sebesar 0,302 > 0,05 sehingga dapat disimpulkan bahwa data yang di uji berdistribusi normal.

Tabel 7

\section{Hasil Uji Normalitas}

One-Sample Kolmogorov-Smirnov Test

\begin{tabular}{|ll|r|}
\hline & & $\begin{array}{c}\text { Unstandardized } \\
\text { Residual }\end{array}$ \\
\hline $\mathrm{N}$ & & 120 \\
Normal Parameters & Mean & .0000000 \\
& Std. Deviation & 1.92187150 \\
Most Extreme Differences & Absolute & .089 \\
& Positive & .044 \\
Kolmogorov-Smirnov Z & Negative & -.089 \\
Asymp. Sig. (2-tailed) & & .971 \\
a. Test distribution is Normal. & & .302 \\
b. Calculated from data. & & \\
\hline
\end{tabular}

\section{TEKNIK ANALISIS DATA}

\section{Analisis Regresi Linear Berganda}

Analisis ini digunakan untuk mengetahui apakah variabel Bukti Langsung, Keandalan, Daya Tanggap, Jaminan dan Kepedulian berpengaruh terhadap Kepuasan Pelanggan listrik prabayar di Kelurahan Ngipik, Kecamatan Gresik. Pengujian dilakukan dengan menggunakan SPSS versi 17 didapatkan hasil sebagai berikut:

$$
Y=-5,489+0,280 X_{1}+0,260 X_{2}+0,416 X_{3}+0,275 X_{4}+0,357 X_{5}+e
$$

\section{Tabel 8}

Hasil Uji Regresi Linear Berganda

Coefficients $^{\mathrm{a}}$

\begin{tabular}{|c|c|c|c|c|c|c|}
\hline \multirow{2}{*}{\multicolumn{2}{|c|}{ Model }} & \multicolumn{2}{|c|}{ Unstandardized Coefficients } & \multirow{2}{*}{$\begin{array}{c}\begin{array}{c}\text { Standardized } \\
\text { Coefficients }\end{array} \\
\text { Beta }\end{array}$} & \multirow[b]{2}{*}{$\mathrm{T}$} & \multirow[b]{2}{*}{ Sig. } \\
\hline & & $\mathrm{B}$ & Std. Error & & & \\
\hline \multirow[t]{6}{*}{1} & (Constant) & -5.489 & 2.489 & & -2.205 & .029 \\
\hline & $\begin{array}{l}\text { Bukti } \\
\text { Langsung }\end{array}$ & .280 & .078 & .268 & 3.571 & .001 \\
\hline & Keandalan & .260 & .091 & .229 & 2.856 & .005 \\
\hline & $\begin{array}{l}\text { Daya } \\
\text { Tanggap }\end{array}$ & .416 & .154 & .234 & 2.696 & .008 \\
\hline & Jaminan & .275 & .090 & .241 & 3.039 & .003 \\
\hline & Kepedulian & .357 & .105 & .270 & 3.410 & .001 \\
\hline
\end{tabular}

a. Dependent Variable: kepuasan pelanggan

\section{Koefisien Determinasi}

Koefisien determinasi $\left(\mathrm{R}^{2}\right)$ pada intinya mengukur seberapa jauh kemampuan menjelaskan variabel independen terhadap variabel dependen. Koefisien determinasi $\left(\mathrm{R}^{2}\right)$ dapat dilihat pada tabel sebagai berikut: 
Tabel 9

Hasil Uji Koefisien Determinasi $\left(\mathbf{R}^{2}\right)$

\begin{tabular}{|l|r|r|r|r|}
\hline \multicolumn{1}{|c|}{ Model Summary $^{\mathbf{b}}$} \\
\hline 1 & \multicolumn{1}{c|}{$\mathrm{R}$} & R Square & Adjusted R Square & Std. Error of the Estimate \\
\hline & $.632^{\mathrm{a}}$ & .400 & .374 & 1.964 \\
\hline
\end{tabular}

a. Predictors: (Constant), bukti langsung, keandalan, daya tanggap, jaminan dan kepedulian

b. Dependent Variable: kepuasan pelanggan

\section{Uji Hipotesis}

Untuk mengetahui masing-masing apakah variabel bebas $(\mathrm{X})$ secara parsial mempunyai pengaruh terhadap variabel terikat (Y)

Tabel 10

Hasil Uji $t$

Coefficients $^{\mathbf{a}}$

\begin{tabular}{|c|c|c|c|c|c|c|}
\hline \multirow{2}{*}{\multicolumn{2}{|c|}{ Model }} & \multicolumn{2}{|c|}{ Unstandardized Coefficients } & \multirow{2}{*}{$\begin{array}{c}\begin{array}{c}\text { Standardized } \\
\text { Coefficients }\end{array} \\
\text { Beta }\end{array}$} & \multirow[b]{2}{*}{$\mathrm{T}$} & \multirow[b]{2}{*}{ Sig. } \\
\hline & & B & Std. Error & & & \\
\hline \multirow[t]{6}{*}{1} & (Constant) & -5.489 & 2.489 & & -2.205 & .029 \\
\hline & $\begin{array}{l}\text { Bukti } \\
\text { Langsung }\end{array}$ & .280 & .078 & .268 & 3.571 & .001 \\
\hline & Keandalan & .260 & .091 & .229 & 2.856 & .005 \\
\hline & $\begin{array}{l}\text { Daya } \\
\text { Tanggap }\end{array}$ & .416 & .154 & .234 & 2.696 & .008 \\
\hline & Jaminan & .275 & .090 & .241 & 3.039 & .003 \\
\hline & Kepedulian & .357 & .105 & .270 & 3.410 & .001 \\
\hline
\end{tabular}

Hasil pengujian terhadap variabel bukti langsung dapat diperoleh $\mathrm{t}$ hitung sebesar 3,571 > t tabel sebesar 1,980, dengan signifikan sebesar 5\%, maka $\mathrm{H}_{0}$ ditolak dan $\mathrm{H}_{\mathrm{a}}$ diterima. Dengan demikian hasil perhitungan statistik menunjukkan bahwa secara parsial variabel bukti langsung berpengaruh signifikan terhadap kepuasan pelanggan listrik prabayar PT. PLN (Persero) Gresik, studi kasus: Kelurahan Ngipik, Kecamatan Gresik.

\section{INTERPRETASI HASIL}

\section{Pengaruh Bukti Langsung Terhadap Kepuasan Pelanggan}

Variabel Bukti Langsung (X1) terbukti berpengaruh positif dan signifikan terhadap Kepuasan Pelanggan (Y) listrik prabayar di PT.PLN (Persero) Gresik, Kelurahan Ngipik, Kecamatan Gresik. hal ini diperkuat dengan jurnal penelitian dari Izogo dan Ogba (2015) menyatakan bahwa bukti fisik atau bukti langsung mempunyai hubungan yang positif terhadap kepuasan pelanggan, karena semakin bagus kualitas bukti fisik atau bukti langsung yang ditawarkan maka akan meningkatkan kepuasan pelanggan. 


\section{Pengaruh Keandalan Terhadap Kepuasan Pelanggan}

Variabel Keandalan (X2) terbukti berpengaruh positif dan signifikan terhadap Kepuasan Pela nggan (Y) listrik prabayar di PT.PLN (Persero) Gresik, Kelurahan Ngipik, Kecamatan Gresik. Hal ini diperkuat dengan jurnal penelitian Umboh dan Mandey (2014) juga menyatakan bahwa keadalan mempunyai hubungan yang positif terhadap kepuasan pelanggan.

\section{Pengaruh Daya Tanggap Terhadap Kepuasan Pelanggan}

Variabel Daya Tanggap (X3) terbukti berpengaruh positif dan signifikan terhadap Kepuasan Pelanggan (Y) listrik prabayar di PT.PLN (Persero) Gresik, Kelurahan Ngipik, Kecamatan Gresik. Hal ini diperkuat dengan jurnal penelitian Sulistyawati (2015) yang juga menyatakan bahwa daya tanggap mempunyai hubungan yang positif terhadap kepuasan pelanggan

\section{Pengaruh Jaminan Terhadap Kepuasan Pelanggan}

Variabel Jaminan (X4) terbukti berpengaruh positif dan signifikan terhadap Kepuasan Pelanggan (Y) listrik prabayar di PT.PLN (Persero) Gresik, Kelurahan Ngipik, Kecamatan Gresik. Hal ini diperkuat dengan jurnal penelitian Seminari (2015) yang juga menyatakan bahwasanya jaminan mempunyai hubungan yang positif terhadap kepuasan pelanggan.

\section{Pengaruh Kepedulian Terhadap Kepuasan Pelanggan}

Variabel Kepedulian (X5) terbukti berpengaruh positif dan signifikan terhadap Kepuasan Pelanggan (Y) listrik prabayar di PT.PLN (Persero) Gresik, Kelurahan Ngipik, Kecamatan Gresik. Hal ini diperkuat dengan jurnal penelitian Aryani dan Febina (2010), juga menemukan bahwa empati mempunyai hubungan yang positif dan terhadap kepuasan pelanggan.

\section{KESIMPULAN DAN REKOMENDASI}

\section{Kesimpulan}

Berdasarkan hasil penelitian dan pembahasan yang telah dikemukakan pada bab sebelumnya, maka dalam penelitian ini dapat diambil beberapa kesimpulan sebagai berikut :

1. Variabel Bukti Langsung $\left(\mathrm{X}_{1}\right)$ berpengaruh secara parsial terhadap Kepuasan Pelanggan (Y) PT. PLN (Persero) Gresik, Kecamatan Gresik.

2. Variabel Keandalan $\left(\mathrm{X}_{2}\right)$ berpengaruh secara parsial terhadap Kepuasan Pelanggan (Y) PT. PLN (Persero) Gresik, Kecamatan Gresik.

3. Variabel Daya Tanggap $\left(\mathrm{X}_{3}\right)$ berpengaruh secara parsial terhadap Kepuaan Pelanggan (Y) PT. PLN (Persero) Gresik, Kecamatan Gresik.

4. Variabel Jaminan $\left(\mathrm{X}_{4}\right)$ berpengaruh secara parsial terhadap Kepuasan Pelanggan (Y) PT. PLN (Persero) Gresik, Kecamatan Gresik. 
5. Variabel Kepedulian $\left(\mathrm{X}_{5}\right)$ berpengaruh secara parsial terhadap Kepuasan Pelanggan (Y) PT. PLN (Persero) Gresik, Kecamatan Gresik.

\section{Rekomendasi}

Berdasarkan hasil analisis, pembahasan dan kesimpulan penelitian, maka rekomendasikan dari penelitian ini adalah sebagai berikut :

1. Bagi Perusahaan

Bukti langsung, Keandalan, Daya tanggap, Jaminan dan Kepedulian berkaitan dengan kualitas layanan di perusahaan harus tetap di pertahankan dan ditingkatkan guna meningkatkan kepuasan pelanggan listrik prabayar PT.PLN (Persero) Gresik.

2. Bagi peneliti selanjutnya

Bagi peneliti selanjutnya diharapkan untuk menambah variabel-variabel yang lainnya seperti Inovasi, Kualitas Produk, Harga, Nilai Pelanggan. Serta menggunakan teknik analisis yang berbeda seperti analisis jalur. Menjadikan variabel kepedulian sebagai variabel intervening. Peneliti selanjutnya diharapkan mencoba menggali aspek-aspek yang belum dibahas dalam penelitian ini sebagai pengembangan penelitian.

\section{DAFTAR PUSTAKA}

Fandy Tjiptono. 2012. Strategi Pemasaran, ed. 3, Yogyakarta, Andi.

Izogo, Ernest Emeka \& Ogba, Ike-Elechi. (2015). Service quality, customer satisfaction and loyalty in automobile repair services sector. Nigeria: Ebonyi State University

Kotler, Philip \& Keller, Kevin Lane. 2009. Manajemen Pemasaran, Edisi 13, Jilid 1, Penerbit Erlangga, Jakarta.

Kotler, Philip and Gary Armstrong. 2008. Prinsip - prinsip pemasaran. Edisi. 12. Jilid 1. Jakarta: Erlangga

Siskawati, 2019. Pengaruh Kualitas Pelayanan dan Inovasi Terhadap Kepuasan Pelanggan Pada PT.PLN (persero) Area Manado, Jurnal EMBA Vol.7 No.1 Januari 2019.

Sugiyono, 2015. Metode Penelitian Pendidikan, Penelitian Kuantitatif, Dan $R \& B$, Cetakan Ke-23, Bandung : Alfabeta.

Valdo J. Umboh dan Silvya L. Mandey, 2014, Analisis Kualitas Jasa Layanan Pengaruhnya Terhadap Kepuasan Nasabah Pada Pt. Pegadaian (Persero) Cabang Teling. Jurnal EMBA Volume 2 No 3 September tahun 2014, hal 654-663.

Wijaya, Tony. 2018. Manajemen Kualitas Jasa Desain Servqual. Jakarta: PT. Indeks. 